\title{
PENGARUH DURASI, KONVEKSITAS, DAN INFLASI TERHADAP HARGA OBLIGASI KORPORASI DI BURSA EFEK INDONESIA
}

\author{
Ni Putu Rika Puspa Astari ${ }^{1}$ \\ Ida Bagus Badjra ${ }^{2}$ \\ ${ }^{1,2}$ Fakultas Ekonomi dan Bisnis, Universitas Udayana, Bali, Indonesia \\ email: rikapuspa.astari@gmail.com
}

\begin{abstract}
ABSTRAK
Obligasi korporasi merupakan surat hutang yang dikeluarkan oleh perusahaan. Harga obligasi kororasi bersifat fluktuatif dan dipengaruhi oleh beragam faktor internal dan eksternal dari obligasi itu sendiri. Tujuan penelitian ini adalah untuk menganalisis pengaruh durasi, konveksitas dan inflasi terhadap harga obligasi korporasi di Bursa Efek Indonesia (BEI) selama tahun 2014-2016. Penelitian ini menggunakan data sekunder yang diperoleh melalui laman resmi Indonesia Bond Pricing Agency (IBPA), Bank Indonesia (BI), The Indonesia Capital Market Institute (TICMI) dan PT. Kustodian Sentral Efek Jakarta (PT. KSEI). Sampel berjumlah 36 obligasi yang ditentukan menggunakan metode purposive sampling dan dianalisis menggunakan teknik analisis regresi linier berganda. Hasil analisis memperlihatkan bahwa durasi berpengaruh positif signifikan terhadap harga obligasi. Konveksitas berpengaruh negatif dan tidak signifikan terhadap harga obligasi. Inflasi berpengaruh positif dan tidak signifikan terhadap harga obligasi. Implikasi penelitian ini adalah investor dapat menggunakan durasi untuk mengukur sensitivitas harga obligasi terhadap perubahan suku bunga.

Kata kunci: durasi, konveksitas, inflasi, harga obligasi
\end{abstract}

\begin{abstract}
Corporate bond is a debt note which is had by company. Corporate bond price is fluctuative and influenced by many internal and external factors. This study aims to determine the effect of duration, convexity and inflation to corporate bond price in IDX for 2014 until 2016. The research data is secondary obtained from IBPA, BI, TICMI and PT. KSEI. There are 36 samples which is determined by purposive sampling method and analyzed by multiple linear regression technique. The analysis result shows that duration has a positive and significant effect to bond price. Convexity has a negative and not significant effect to bond prices. Inflation has positive and not significant effect to bond prices. The research implication is duration can be used by investor to measure bond price sensitivity toward interest rate change.
\end{abstract}

Keywords: duration, convexity, inflation, bond price 


\section{PENDAHULUAN}

Investasi obligasi di Indonesia semakin berkembang melalui sinergi antara penerbit obligasi, pemegang obligasi (investor) dan pemerintah selaku regulator. Bursa Efek Indonesia (BEI) mencatat bahwa terdapat total 65 emisi obligasi dan sukuk dari 44 emiten senilai Rp 90,53 triliun sepanjang tahun 2016. Banyaknya obligasi jatuh tempo memicu meningkatnya kuantitas penerbitan obligasi di kuartal IV tahun 2016. Total obligasi jatuh tempo pada periode Oktober hingga Desember 2016 mencapai Rp 13,9 triliun (www.ibpa.co.id).

Tren suku bunga rendah serta dipangkasnya tingkat suku bunga Bank Indonesia 7 days reverse repo menjadi 5\% juga memicu ramainya penerbitan obligasi karena perusahaan membutuhkan pendanaan untuk ekspansi. Permintaan obligasi khususnya oleh investor dalam negeri juga meningkat akibat penurunan tingkat suku bunga obligasi pemerintah di hampir semua tenor. Dukungan serupa juga ditunjukkan oleh Otoritas Jasa Keuangan (OJK) dengan menyusun mekanisme pelaporan transaksi efek surat utang dan sukuk untuk meningkatkan integritas pasar, memperbaiki kualitas pembentukan harga di pasar dan memperkuat pengawasan transaksi obligasi (www.ibpa.co.id).

Perusahaan dalam kegiatan usahanya dapat menerbitkan obligasi sebagai salah satu sumber pendanaan jangka panjang. Obligasi juga dapat dijadikan sebagai salah satu instrumen investasi. Investor atau pemegang obligasi dapat membiarkan obligasi sampai tiba jatuh tempo untuk memperoleh yield to maturity (YTM) maupun diperjualbelikan untuk memperoleh capital gain. Tandelilin (2010:245) menyatakan bahwa obligasi (bond) merupakan surat hutang yang memberikan janji 
Ni Putu Rika Puspa Astari, Pengaruh Durasi, Konveksitas dan...

berupa pemberian bunga atau kupon obligasi secara rutin kepada pemiliknya serta melunasi obligasi apabila jatuh tempo itu tiba. Obligasi (bond) merupakan perjanjian berjangka panjang dan penerbit setuju untuk membayarkan bunga dan pokok pinjaman pada pemilik obligasi di waktu tertentu (Brigham dan Houston, 2011:345). Hartono (2016:210) mendefinisikan obligasi sebagai utang berjangka waktu panjang yang nantinya dibayarkan kembali saat jatuh tempo dengan bunga tetap.

Obligasi korporasi menjadi salah satu jenis surat utang yang diperjualbelikan pada pasar modal. Obligasi korporasi adalah obligasi yang dikeluarkan oleh korporasi swasta maupun nasional diantaranya Badan Usaha Milik Negara (BUMN) dan Badan Usaha Milik Daerah (BUMD) (Purba, 2016). Obligasi korporasi menurut investor didefinisikan sebagai suatu investasi yang memiliki karakteristik lain tidak seperti saham biasa. Saham biasa memuat klaim kepemilikan atas sebuah perusahaan, sementara obligasi memuat klaim pemegang obligasi pada sebuah perusahaan (Tandelilin, 2010:245). Obligasi korporasi memiliki satuan harga yang dijadikan sebagai acuan dalam bertransaksi.

Harga obligasi dapat diketahui dengan melakukan pendiskontoan terhadap seluruh aliran kas yang berasal dari penerimaan bunga obligasi ditambahkan dengan jumlah nominal obligasi yang diterima saat obligasi jatuh tempo, dilengkapi yield sesuai syarat investor (Tandelilin, 2010:271). Harga obligasi dinyatakan dengan persentase dari nilai nominalnya (Tandelilin, 2010:274). Harga suatu obligasi telah ditetapkan sesuai dengan mekanisme juar beli pada pasar modal melewati transaksi bursa atau Over The Counter (OTC) (Sari dan Sudjarni, 2016). 
Tabel 1 menyajikan beberapa obligasi korporasi yang paling aktif diperdagangkan pada tahun 2016 .

Tabel 1.

Obligasi Korporasi yang Paling Aktif Ditransaksikan Tahun 2016

\begin{tabular}{lrrr}
\hline \multicolumn{1}{c}{ Seri } & Harga (\%) & $\begin{array}{c}\text { Nilai } \\
\text { Nominal } \\
\text { (juta) }\end{array}$ & $\begin{array}{c}\text { Harga } \\
\text { Obligasi } \\
\text { (Juta) }\end{array}$ \\
\hline BBRI01BCN2 & 106,00 & 1.018 .500 & 1.079 .610 \\
BDKI01CN1 & 100,02 & 1.000 .000 & 1.002 .000 \\
BBRI01BCN3 & 99,75 & 2.437 .000 & $2.430 .907,5$ \\
BMRI01ACN1 & 100,22 & 1.100 .000 & 1.102 .420 \\
BMRI01BCN1 & 98,85 & 1.500 .000 & 1.482 .750 \\
BSSB01CN1 & 101,40 & 500.000 & 507.000 \\
BPFI01BCN1 & 99,50 & 170.000 & 169.150 \\
ISAT01DCN2 & 114,00 & 337.000 & 384.180 \\
GWSA01CN & 100,04 & 72.000 & $72.028,8$ \\
PJAA01ACN1 & 100,15 & 250.000 & 250.375 \\
\hline
\end{tabular}

Sumber: www.bareksa.com, 2017

Tabel 1 menunjukkan bahwa persentase harga obligasi di atas $100 \%$ berarti harga obligasi tersebut mengalami peningkatan dari nilai nominalnya. Persentase harga obligasi di bawah $100 \%$ berarti harga obligasi tersebut menurun dibanding nilai nominalnya. Harga obligasi dengan seri ISAT01DCN2 mengalami peningkatan paling besar yaitu sebanyak $14 \%$ dari nilai nominalnya. Penurunan harga obligasi terbesar justru dialami oleh obligasi seri BMRI01BCN1 sebesar $1,15 \%$ dari nilai nominalnya.

Harga obligasi bersifat fluktuatif mengikuti mekanisme permintaan dan penawaran investor. Pemegang obligasi harus mempertimbangkan berbagai faktor yang mempengaruhi harga obligasi dengan karakteristik yang melekat pada obligasi tersebut diantaranya yield, maturitas, kupon, durasi, konveksitas dan peringkat obligasi (Tandelilin, 2010:276-280). Harga obligasi juga rentan terhadap 
variabel makroekonomi diantaranya suku bunga, nilai tukar dan inflasi (Giri, 2016). Variabel yield, maturitas dan kupon dipergunakan untuk mengetahui besaran durasi dan konveksitas. Variabel inflasi dipilih karena mampu secara langsung mempengaruhi fluktuasi harga obligasi yang ditransaksikan di dalam negeri. Durasi, konveksitas dan inflasi akan dibahas secara mendalam dalam penelitian ini untuk menganalisis signifikansi pengaruh variabel tersebut terhadap harga dari obligasi korporasi.

Durasi menjadi faktor pertama yang menyebabkan fluktuasi harga obligasi. Durasi menjadi salah satu dasar penilaian harga obligasi saat ini. Durasi menilai rata-rata tertimbang jangka waktu aliran kas obligasi menggunakan nilai saat ini (present value) (Tandelilin, 2010:281). Maturitas, kupon dan YTM-nya menentukan lamanya durasi obligasi. Durasi memiliki fungsi yang lebih baik dalam menilai sensitivitas harga obligasi akibat perubahan suku bunga, karena durasi telah menggabungkan nilai kupon dan jangka waktu obligasi (Tandelilin, 2010:283). Nilai durasi yang besar menyebabkan potensi perubahan harga obligasi akibat perubahan suku bunga juga bertambah besar (Hanafi, 2012:139).

Alouj et al. (2002) dan Gajek et al. (2005) menyatakan pendapatnya yakni durasi memiliki pengaruh positif pada harga obligasi. Shirvani dan Wilbratte (2005) berpendapat bahwa durasi memberikan pengaruh yang positif dan signifikan pada harga obligasi. Hal serupa dikatakan oleh Hamid dkk. (2006) yang berpendapat bahwa durasi mampu difungsikan untuk memprediksi nilai sensitivitas harga obligasi akibat perubahan suku bunga. Pernyataan berbeda ditunjukkan oleh Lena (2003) menyatakan bahwa durasi tidak berpengaruh terhadap harga obligasi. 
Wahyuningsih (2013) juga berpendapat bahwa ada pengaruh negatif signifikan antara durasi obligasi dan harga suatu obligasi.

Faktor kedua yang mempengaruhi harga obligasi adalah konveksitas. Nilai konveksitas obligasi mencerminkan perubahan harga obligasi karena faktor kelengkungan (konveksitas) fungsi harga (Sunaryo, 2007:69). Fabozzi (2000:73) menyatakan bahwa konveksitas digunakan untuk menghasilkan perkiraan lebih baik terkait perubahan harga obligasi jika tingkat hasil yang diinginkan berubah. Konveksitas menunjukkan seberapa cembung kurva obligasi antara harga dengan yield. Konveksitas kurva sebuah obligasi memiliki arti bahwa fluktuasi harga tak simetris saat terjadi perubahan yield. Apabila kurva konveksitas semakin cembung, itu tersebut berarti harga suatu obligasi lebih sensitif jika terjadi fluktuasi yield (Kusuma dan Asrori, 2005).

Hahn dan Lange (2008) mengatakan bahwa konveksitas memiliki hubungan searah (positif) dan signifikan terhadap harga obligasi. Cerovic et al. (2014) juga mengungkapkan bahwa konveksitas memperlihatkan pengaruh yang positif pada harga obligasi. Maruddani dan Hoyyi (2017) mengatakan konveksitas berpengaruh dalam mengukur sensitivitas harga obligasi. Hasil yang bertolak belakang disebutkan oleh Kusuma dan Asrori (2005) yang mengatakan konveksitas berpengaruh negatif dan tidak signifikan pada harga suatu obligasi.

Faktor terakhir yang mempengaruhi harga obligasi adalah inflasi. Inflasi merupakan variabel makroekonomi yang menunjukkan keadaan dimana harga barang meningkat secara terus menerus sehingga menyebabkan kondisi perekonomian melemah (Widoatmojo, 2008:57). Tingkat inflasi sangat 
Ni Putu Rika Puspa Astari, Pengaruh Durasi, Konveksitas dan...

diperhitungkan oleh investor dalam mengambil keputusan investasi termasuk investasi obligasi. Inflasi yang nilainya lebih tinggi dari nilai obligasi akan menyebabkan kerugian bagi investor. Inflasi menyebabkan penurunan daya beli investor terhadap aset keuangan termasuk obligasi, sehingga permintaan pada aktiva finansial akan melemah dan berdampak pada penurunan harga obligasi (Hadian, 2013).

Penelitian yang dilakukan oleh Barr (1997) serta Kang dan Pflueger (2012) mengungkapkan inflasi memperlihatkan pengaruh negatif terhadap harga obligasi. Hal serupa diungkapkan Hordahl dan Tristani (2014) yang mengatakan bahwa inflasi berdampak negatif dan signifikan pada harga obligasi. Hasil berbanding terbalik diungkapkan Widajati (2009) yaitu inflasi tidak mempengaruhi harga obligasi. Azizah dan Hidajat (2016) juga mengungkapkan hasil dimana inflasi berdampak secara positif namun tidak signifikan pada harga suatu obligasi.

Perbedaan hasil penelitian terdahulu terkait hubungan variabel bebas dan variabel terikat menunjukkan bahwa perlu dilakukan penelitian lebih lanjut. Penelitian ini penting dilakukan agar investor mampu mengambil keputusan investasi obligasi dengan tepat, mengingat transaksi obligasi korporasi semakin meningkat yang berdampak pada semakin fluktuatifnya harga obligasi. Obligasi korporasi dipilih karena memiliki eksposur risiko yang lebih tinggi terhadap variabel makroekonomi dan variabel yang merupakan karakteristik obligasi itu sendiri. Variabel makroekonomi yang diteliti adalah inflasi. Durasi dan konveksitas adalah variabel penelitian yang menjadi karakteristik dari obligasi korporasi. Perubahan harga obligasi korporasi cenderung dipengaruhi oleh mekanisme pasar, 
jenis perusahaan maupun kebijakan pemerintah. Penelitian ini secara khusus mengkaji pengaruh durasi, konveksitas, dan inflasi terhadap harga obligasi korporasi pada BEI selama tahun 2014-2016.

Tujuan penelitian ini yaitu mengetahui signifikansi pengaruh masing-masing variabel durasi, konveksitas dan inflasi terhadap harga obligasi korporasi. Penelitian ini secara teoritis diharapkan mampu memberikan bukti empiris terkait faktor-faktor yang membawa pengaruh pada perubahan harga obligasi dan menjadi sumber informasi bagi peneliti selanjutnya. Kegunaan penelitian secara praktis dari yakni menjadi landasan bagi investor dalam menentukan keputusan investasi, membantu investor dalam memutuskan timing untuk membeli atau menjual suatu obligasi agar memperoleh capital gain, dan membantu perusahaan penerbit dalam menentukan tingkat kupon obligasi.

Obligasi adalah surat pernyataan hutang dari sebuah entitas yang dilengkapi janji guna membayar kupon bunga sesuai besaran yang ditetapkan (Wiagustini, 2014:26). Sunariyah (2011:217) mengungkapkan bahwa obligasi merupakan surat pernyataan hutang akibat adanya dana yang diperoleh perusahaan selaku penerbit obligasi dari pihak yang memegang obligasi. Tandelilin (2010:245) menyatakan bahwa obligasi perusahaan (corporate bond) adalah kewajiban pembayaran yang diberikan perusahaan untuk pemegangnya. Obligasi perusahaan (corporate bond) didefinisikan sebagai surat utang dalam jangka panjang yang dibuat dan diperdagangkan oleh perusahaan swasta dengan nilai hutang dilunasi kembali jika jatuh tempo telah tiba dengan pemberian kupon atau tidak yang telah dimuat dalam kesepakatan (Hartono, 2016:187). 
Ni Putu Rika Puspa Astari, Pengaruh Durasi, Konveksitas dan...

Harga suatu obligasi yang beredar di pasar pada dasarnya ditentukan oleh keputusan apakah obligasi tersebut dijual pada, di atas, atau di bawah nilai par-nya. Seperti yang telah diketahui, harga obligasi dinyatakan dalam unit persentase (\%) dari nilai nominalnya (Tandelilin, 2010: 274). Tingkat kupon dan tingkat bunga pasar menjadi penentu harga suatu obligasi. Harga suatu obligasi berada di atas $100 \%$ jika nilai kupon lebih tinggi daripada suku bunga pasar, sebaliknya harganya akan berada di bawah $100 \%$ apabila nilai kupon lebih rendah dari besaran suku bunga pasar (Manurung dan Rizky, 2009:157). Harga pasar obligasi sifatnya fluktuatif dikarenakan oleh beberapa hal diantaranya terdapat perubahan harga obligasi diskonto dan obligasi premi dan terdapat perubahan dalam hasil yang diinginkan yang disebabkan oleh perubahan hasil pada obligasi-obligasi pembanding (Fabozzi, 2000:545).

Perhitungan nilai atau harga obligasi dapat menggunakan persamaan 1 berikut ini (kupon dibayarkan 2 kali setahun) (Tandelilin, 2010:272):

$P=\sum_{t=1}^{n} \frac{C i / 2}{(1+r / 2)^{t}}+\frac{P p}{(1+r / 2)^{n}}$

Keterangan:

$\mathrm{P} \quad=$ nilai sekarang obligasi

$\mathrm{n} \quad=$ jangka waktu hingga obligasi jatuh tempo

$\mathrm{t} \quad=$ batas bawah jangka waktu obligasi

$\mathrm{Ci}=$ besaran kupon yang diterima setiap tahun

$\mathrm{r} \quad=$ suku bunga pasar

$\mathrm{Pp}=$ nilai par

Volatilitas dari harga suatu obligasi diperoleh melalui sebuah teknik hitung yang dinamakan durasi (duration). Durasi dirumuskan oleh Frederick Macaulay untuk pertama kalinya di tahun 1938. Durasi disebut sebagai rata-rata tertimbang 
hingga jangka waktu berakhir (jatuh tempo) dari arus kas suatu sekuritas dengan pendapatan tetap (Manurung, 2006: 40). Durasi menghitung rata-rata tertimbang jangka waktu aliran kas obligasi menggunakan konsep besaran saat ini (present value). Durasi sebuah obligasi memiliki besaran yang sama dengan total tahun yang dibutuhkan agar dapat mengembalikan harga pengembalian obligasi tersebut (Tandelilin, 2010:281). Lamanya durasi bergantung pada tiga faktor diantaranya jangka waktu obligasi, perolehan kupon dan YTM-nya (Tandelilin, 2010:283). Nilai durasi akan bertambah besar apabila maturitas aset bertambah panjang, berkurang jika yield bertambah, dan berkurang apabila nilai kupon bertambah (Hanafi, 2012: 134-137). Semakin meningkat durasi, maka semakin berisiko pula perubahan harga pasar obligasi akibat fluktuasi suku bunga (Hanafi, 2012:139).

Sarkar (1999) memiliki pendapat bahwa durasi berpengaruh terhadap harga obligasi. Fruhwirth (2002) mengungkapkan durasi mempunyai pengaruh positif dan signifikan pada harga suatu obligasi. Sotos (2004) berpendapat bahwa durasi berpengaruh dalam menentukan sensitivitas harga obligasi. Pernyataan tersebut juga didukung oleh Kusuma dan Asrori (2005) serta Hahn dan Lange (2008) yang mengungkapkan bahwa durasi memiliki pengaruh positif pada harga obligasi.

$\mathrm{H}_{1}$ : Durasi berpengaruh positif signifikan terhadap harga obligasi.

Konveksitas didefinisikan sebagai turunan kedua fungsi harga obligasi yang dibandingkan dengan yield. Nilai konveksitas selalu positif karena nilai waktu jatuh tempo, suku bunga kupon, dan yield selalu positif (Sunaryo, 2007:67). Konveksitas didefinisikan sebagai acuan kecembungan kurva yang memperlihatkan korelasi antara harga sebuah obligasi dengan YTM-nya. Konveksitas menilai ukuran 
Ni Putu Rika Puspa Astari, Pengaruh Durasi, Konveksitas dan...

penyimpangan kurva price-yield dari fungsi liniernya. Semakin konveks kurva price-yield suatu obligasi, maka harga sebuah obligasi menjadi semakin sensitif saat terjadi perbedaan hasil serahan. Konveksitas memperlihatkan fluktuasi harga tak simetris jika terjadi peningkatan maupun penurunan yield (Kusuma dan Asrori, 2005).

Sotos (2004) menyatakan bahwa konveksitas berpengaruh dalam menentukan sensitivitas harga obligasi. Hamid dkk. (2005) menyatakan bahwa konsep convexity mempunyai pengaruh yang positif dan signifikan pada harga obligasi. Hahn dan Lange (2008) serta Alouj et al. (2012) juga mengungkapkan pendapat yakni konveksitas mempengaruhi harga obligasi dalam arah yang positif. Pernyataan tersebut juga didukung oleh Lajili dan Rakotondratsimba (2012) yang mengungkapkan bahwa konveksitas memperlihatkan pengaruh positif pada harga sebuah obligasi.

$\mathrm{H}_{2}$ : Konveksitas berpengaruh positif signifikan terhadap harga obligasi.

Inflasi adalah tahapan dimana terjadi peningkatan harga komoditas secara berkesinambungan yang berakibat pada penurunan daya beli masyarakat dan menurunkan pendapatan secara riil (Putong, 2013:144). Inflasi sangat berpengaruh terhadap keputusan investasi termasuk obligasi. Investor mengharapkan inflasi yang lebih rendah dari investasi agar tidak mengalami kerugian (Azizah dan Hidajat, 2016). Jika inflasi naik, maka daya beli turun, orang lebih mengutamakan konsumsi daripada investasi, sehingga daya beli terhadap obligasi menurun. Penurunan daya beli tersebut berdampak pada menurunnya harga obligasi (Sukanto dan Widaryanti, 2015). 
Kang dan Pflueger (2012) menyatakan bahwa inflasi berpengaruh negatif terhadap harga obligasi. Pernyataan tersebut didukung oleh Hordahl dan Tristani (2014) serta Sukanto dan Widaryanti (2015) yang berpendapat inflasi memperlihatkan pengaruh negatif dan signifikan pada harga obligasi. Rose dan Spiegel (2015) juga mengungkapkan bahwa ada hubungan negatif antara inflasi dan harga obligasi.

$\mathrm{H}_{3}$ : Inflasi berpengaruh negatif signifikan terhadap harga obligasi.

\section{METODE PENELITIAN}

Sifat penelitian ini adalah asosiatif, yang meneliti hubungan antara tiga variabel ataupun lebih (Sugiyono: 2012). Tujuan penelitian ini untuk mengetahui pengaruh variabel bebas (Durasi, Konveksitas, dan Inflasi) terhadap variabel terikat (Harga Obligasi).

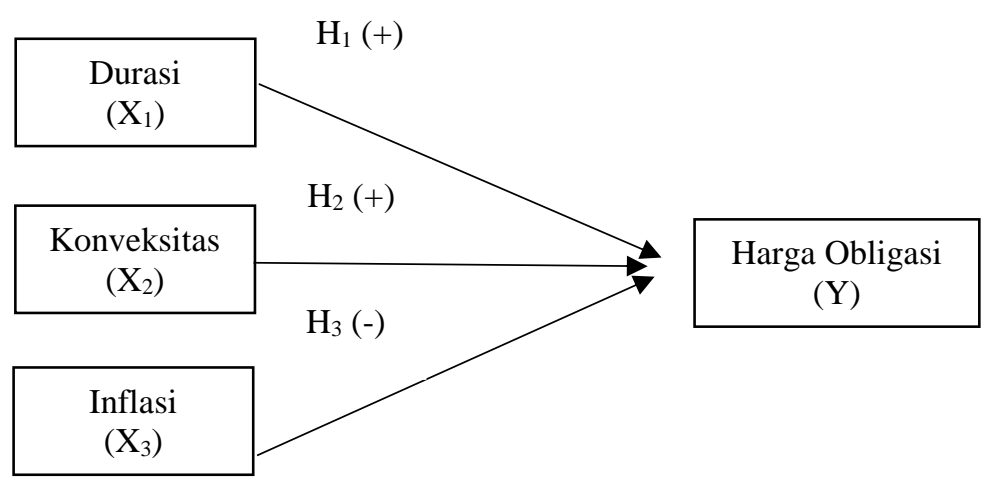

\section{Gambar 1. Kerangka Konseptual Penelitian}

Sumber: Data diolah, 2017

Obyek dalam penelitian adalah harga obligasi korporasi pada BEI periode 2014-2016. Variabel dependent/terikat yang diteliti adalah Harga Obligasi (Y). Variabel independent/bebas yang dianalisis adalah durasi (X1), konveksitas (X2) dan inflasi (X3). 
Ni Putu Rika Puspa Astari, Pengaruh Durasi, Konveksitas dan...

Harga obligasi adalah nominal yang merepresentasikan nilai dari suatu obligasi dan dapat digunakan sebagai patokan dalam melakukan transaksi jual beli obligasi. Harga obligasi dalam penelitian ini diukur berdasarkan transaksi perdagangan obligasi korporasi di pasar modal menggunakan nilai perubahan harga obligasi dalam satuan persentase $(\%)$. Perhitungan persentase sensitivitas harga sebuah obligasi dapat dilakukan melalui perhitungan sebagai berikut:

$$
\Delta P=\frac{P-P_{t-1}}{P_{t-1}} \times 100 \%
$$

Keterangan:

$\Delta \mathrm{P} \quad=$ Perubahan harga obligasi

$\mathrm{P} \quad=$ Harga obligasi periode $\mathrm{t}$

$\mathrm{P}_{\mathrm{t}-1} \quad=$ Harga obligasi periode $\mathrm{t}-1$

Durasi memiliki arti rata-rata tertimbang hingga jangka waktu berakhir dari arus kas obligasi korporasi di BEI selama tahun 2014-2016. Durasi yang diteliti ini menggunakan satuan tahun. Durasi dalam penelitian ini diukur menggunakan durasi modifikasi (modified duration) yang terlebih dahulu harus dihitung Durasi Macaulay dari obligasi yang bersangkutan. Rumus matematik durasi macaulay adalah sebagai berikut:

$$
D=\left[\frac{1 C}{(1+y)}+\frac{2 C}{(1+y)^{2}}+\cdots+\frac{n C}{(1+y)^{n}}+\frac{n M}{(1+y)^{n}}\right] \frac{1}{P}
$$

Keterangan:

$\mathrm{C}=$ kupon atau bunga obligasi

$\mathrm{y}=$ hasil serahan

$\mathrm{M}=$ nilai obligasi saat jatuh tempo

$\mathrm{P}=$ harga pasar obligasi

$\mathrm{n}=$ maturitas 
Durasi modifikasi dihitung dengan cara sebagai berikut:

$$
\text { Modified Duration }\left(D^{*}\right)=\frac{\text { Macaulay'sDuration }}{(1+y)}
$$

Konveksitas mencerminkan faktor kelengkungan fungsi harga akibat perbedaan waktu jatuh tempo, tingkat kupon dan yield obligasi korporasi di BEI selama tahun 2014-2016. Konveksitas yang diteliti ini menggunakan satuan tahun. Penelitian ini menggunakan rumus konveksitas sebagai hasil turunan kedua dari harga obligasi dengan membandingkan antara harga dan yield obligasi yaitu:

$$
\text { Convexity }=\frac{\frac{1(2) C}{(1+y)^{1}}+\frac{2(3) C}{(1+y)^{2}}+\cdots+\frac{n(n+1) C}{(1+y)^{n}}+\frac{n(n+1) M}{(1+y)^{n}}}{(1+y)^{2} P}
$$

\section{Keterangan:}

$\mathrm{C}=$ kupon atau bunga obligasi

$\mathrm{y}=$ hasil serahan

$\mathrm{M}=$ nilai obligasi saat jatuh tempo

$\mathrm{n}=$ maturitas

$\mathrm{P}=$ harga pasar

Inflasi dinyatakan sebagai suatu keadaan ekonomi saat terjadi kenaikan harga dengan berkelanjutan dan disertai dengan kenaikan suku bunga serta dapat menyebabkan terjadinya perubahan harga obligasi korporasi. Data inflasi yang diteliti menggunakan data tahunan yang didapat dari www.bi.go.id periode pengamatan 2014-2016 dan dinyatakan sebagai suatu persentase (\%).

Jenis data penelitian yang digunakan adalah data kuantitatif. Data kuantitatif yang diteliti ini diperoleh melalui rangkuman transaksi obligasi korporasi di BEI selama 2014-2016. Sumber data penelitian yaitu menganalisis data sekunder. Data sekunder yang diteliti didapatkan melalui situs resmi BEI, International Bond 
Pricing Agency (IBPA), Bank Indonesia (BI), The Indonesia Capital Market Institute (TICMI) dan PT. Kustodian Sentral Efek Indonesia (PT. KSEI).

Populasi yang diteliti adalah obligasi yang tercatat di BEI pada tahun 20142016 dengan jumlah 303 obligasi. Sampel yang diteliti diseleksi dengan metode non probability sampling yakni purposive sampling dengan jumlah 36 obligasi. Penentuan sampel didasarkan pada kriteria-kriteria tertentu, diantaranya: 1) Obligasi korporasi yang diterbitkan pada tahun 2014-2016 dan berstatus aktif diperdagangkan di BEI pada tahun terbitnya. 2) Obligasi korporasi yang membayar kupon dalam rate tetap (fixed rate bonds) dan memiliki data mengenai variabel yang diteliti. Metode penentuan sampel berdasarkan kriteria tersebut disajikan pada tabel 2 berikut ini.

Tabel 2.

Jumlah Populasi dan Sampel Penelitian

\begin{tabular}{lll}
\hline No & Keterangan & Jumlah \\
\hline 1 & Populasi & 303 obligasi \\
2 & $\begin{array}{l}\text { Obligasi yang tidak diterbitkan tahun 2014-2016 dan tidak aktif } \\
\text { diperdagangkan di BEI }\end{array}$ & 198 obligasi \\
3 & $\begin{array}{l}\text { Obligasi yang tidak membayarkan kupon dalam rate tetap dan } \\
\text { tidak memiliki data mengenai variabel yang diteliti }\end{array}$ & 69 obligasi \\
& Total Sampel & $\mathbf{3 6}$ obligasi \\
\hline
\end{tabular}

Sumber: Data diolah, 2017

Data penelitian dikumpulkan menggunakan metode observasi non partisipan, yakni teknik mengumpulkan data melalui pencatatan tentang data-data yang akan diteliti namun peneliti tidak terlibat langsung dalam aktivitas perusahaan (Sugiyono, 2014:203). Penelitian dilaksanakan dengan cara melihat, mencatat dan menganalisis data obligasi korporasi sesuai dengan variabel penelitian yang dipublikasikan oleh BEI, IBPA, BI, TICMI dan PT. KSEI. Data penelitian 
dianalisis dengan memanfaatkan teknik analisis regresi linier berganda yang memiliki tujuan untuk mengetahui korelasi fungsi antara satu variabel dependent dengan lebih dari satu variabel independent (Utama, 2016:77). Persamaan regresi yang digunakan dapat dilihat pada persamaan 6 berikut ini:

$$
\mathrm{Y}=\mathrm{a}+\mathrm{b}_{1} \mathrm{X}_{1}+\mathrm{b}_{2} \mathrm{X}_{2}+\mathrm{b}_{3} \mathrm{X}_{3}+\mathrm{e}
$$

Keterangan:

Y : Variabel dependent (Harga obligasi)

a : Konstanta

$\mathrm{X}_{1} \quad$ : Durasi

$\mathrm{X}_{2} \quad$ : Konveksitas

$\mathrm{X}_{3} \quad$ : Inflasi

$\mathrm{b}_{1} \quad$ : Koefisien Variabel $\mathrm{X}_{1}$

Penelitian ini juga dilengkapi dengan analisis statistik deskriptif dan dilakukan uji asumsi klasik terlebih dahulu. Uji tersebut penting diketahui sebelum analisis regresi linier berganda dilakukan. Uji asumsi klasik terdiri dari uji autokorelasi, uji multikolinearitas dan uji heteroskedastisitas. Uji kelayakan model (uji F), uji koefisien determinasi dan uji hipotesis (uji t) juga dipergunakan dalam penelitian ini.

\section{HASIL DAN PEMBAHASAN}

Analisis statistik deskriptif menggambarkan karakter variabel penelitian diantaranya Harga Obligasi (Y), Durasi $\left(\mathrm{X}_{1}\right)$, Konveksitas $\left(\mathrm{X}_{2}\right)$, dan Inflasi $\left(\mathrm{X}_{3}\right)$. Analisis statistik deskriptif memuat informasi mengenai jumlah pengamatan, nilai maksimum, nilai minimum, rata-rata (mean) dan standar deviasi. Hasil analisis statistik deskriptif disajikan dalam tabel 3 berikut ini. 
Tabel 3.

Statistik Deskriptif

\begin{tabular}{lrrrrr}
\hline & N & Minimum & Maximum & Mean & $\begin{array}{c}\text { Std. } \\
\text { Deviation }\end{array}$ \\
\hline Durasi & 36 & 0,26 & 2,50 & 1,1314 & 0,54177 \\
Konveksitas & 36 & 4,17 & 70,81 & 23,0306 & 18,46974 \\
Inflasi & 36 & 3,53 & 6,42 & 5,0442 & 1,45265 \\
Harga Obligasi & 36 & $-1,92$ & 4,15 & 0,1428 & 1,06955 \\
\hline
\end{tabular}

Sumber: Data diolah, 2017 (Lampiran 2)

Tabel 3 menggambarkan bahwa variabel harga obligasi memiliki rentang nilai dari $-1,92 \%$ hingga $4,15 \%$ dari total keseluruhan 36 obligasi. Obligasi dengan kode NISP01CCN2 memiliki harga obligasi dengan nilai terendah yaitu $-1,92 \%$, sedangkan harga obligasi yang paling tinggi sebesar 4,15\% jatuh ke obligasi berkode MDLN01BCN1. Mean (rata-rata) dari harga obligasi adalah sebesar $0,1428 \%$ yang berarti bahwa rata-rata harga obligasi dari total 36 obligasi di BEI periode 2014-2016 adalah 0,1428\%. Standar deviasi variabel harga obligasi sebesar 1,06955\% yang berarti bahwa rata-rata variasi harga obligasi di BEI dalam tahun pengamatan menyimpang dari rata-ratanya sebesar $1,06955 \%$.

Variabel durasi memperlihatkan rentang nilai dari 0,26 tahun hingga 2,50 tahun dari total keseluruhan 36 obligasi. Obligasi dengan kode BBIA01ACN1 memiliki nilai durasi terendah sebesar 0,26 tahun, sedangkan nilai durasi tertinggi sebesar 2,50 tahun merujuk ke obligasi berkode ISAT01DCN1. Durasi sebesar 1,1314 tahun merupakan mean variabel durasi yang berarti bahwa rata-rata durasi dari total 36 obligasi di BEI periode 2014-2016 sebesar 1,1314 tahun. Standar deviasi variabel durasi sebesar 0,54177 tahun yang berarti bahwa rata-rata variasi 
durasi obligasi di BEI dalam tahun pengamatan menyimpang dari rata-ratanya sebesar 0,54177 tahun.

Variabel konveksitas menunjukkan rentang nilai dari 4,17 tahun hingga 70,81 tahun dari total keseluruhan 36 obligasi. Obligasi dengan kode BPFI01BCN1 memiliki nilai konveksitas terendah yaitu 4,17 tahun, sedangkan nilai tertinggi sebesar 70,81 tahun dimiliki oleh ISAT01DCN1. Nilai rata-rata (mean) dari konveksitas adalah sebesar 23,0306 tahun yang berarti bahwa rata-rata konveksitas dari total 36 obligasi di BEI periode 2014-2016 sebesar 23,0306 tahun. Standar deviasi variabel konveksitas sebesar 18,46974 tahun yang berarti bahwa rata-rata variasi konveksitas obligasi di BEI dalam tahun pengamatan menyimpang dari mean-nya sebesar 18,46974 tahun.

Variabel inflasi memiliki rentang nilai dari 3,53\% hingga 6,42\% dari total keseluruhan 36 obligasi. Nilai inflasi terendah yaitu sebesar 3,53\%, sedangkan nilai inflasi tertinggi sebesar 6,42\%. Nilai rata-rata (mean) dari inflasi adalah sebesar $5,0442 \%$ yang berarti bahwa rata-rata inflasi dari total 36 obligasi di BEI periode 2014-2016 sebesar 5,0442\%. Standar deviasi variabel inflasi adalah sebesar $1,45625 \%$ yang berarti bahwa rata-rata variasi inflasi obligasi di BEI tahun pengamatan menyimpang dari rata-ratanya sebesar $1,45625 \%$.

Tujuan uji normalitas adalah untuk mengetahui apakah residual variabel yang dianalisis dalam model regresi terdistribusi secara normal atau tidak. Data yang terdistribusi normal ditunjukkan dengan Asymp. Sig. (2-tailed) lebih besar dari level of significant sebesar 0,05, apabila Asymp. Sig. (2-tailed) lebih kecil dari level of significant sebesar 0,05, data tersebut dianggap tidak terdistribusi secara normal. 
Uji statistik non parametrik 1 sample K-S (Kolmogorov-Smirnov) merupakan bentuk uji normalitas yang dianalisis dalam penelitian kali ini. Hasil uji normalitas dipaparkan pada tabel 4.

Tabel 4.

Hasil Uji Normalitas

\begin{tabular}{llr}
\hline & & Unstandardized Residual \\
\hline $\mathrm{N}$ & & 36 \\
Normal Parameters & Mean & $0 \mathrm{E}-7$ \\
& Std. Deviation & 0,91981339 \\
Most Extreme Differences & Absolute & 0,199 \\
& Positive & 0,199 \\
& Negative & $-0,097$ \\
Kolmogorov-Smirnov Z & & 1,195 \\
Asymp. Sig. (2-tailed) & & 0,115 \\
& & \\
\hline
\end{tabular}

Sumber: Data diolah, 2017 (Lampiran 4)

Berdasarkan data yang disajikan di tabel 4 dapat diketahui bahwa nilai Asymp. Sig. (2-tailed) sebesar 0,115 lebih besar dari level of significant sebesar 0,05, maka dapat dikatakan bahwa data yang diolah dalam model regresi terdistribusi normal.

Uji autokorelasi memiliki tujuan untuk menilai model regresi jika terdapat kaitan antara residual pada periode t dengan residual pada periode t-1 (Ghozali, 2012:99). Uji autokorelasi memanfaatkan tabel Durbin Watson atau d-statistik untuk mengungkap gejala autokorelasi dalam model regresi terhadap variabel pengganggunya (disturbance error term). Hasil uji Durbin Watson ditampilkan pada tabel 5 . 
Tabel 5.

Hasil Uji Autokorelasi (DW-test)

\begin{tabular}{lcrcrr}
\hline \multicolumn{7}{c}{ Model Summary $^{\mathbf{b}}$} \\
\hline Model & $\mathrm{R}$ & R Square & $\begin{array}{c}\text { Adjusted R } \\
\text { Square }\end{array}$ & $\begin{array}{c}\text { Std. Error of } \\
\text { the Estimate }\end{array}$ & Durbin-Watson \\
\hline 1 & $.510^{\mathrm{a}}$ & .260 & .191 & .96196 & 1.975 \\
\hline
\end{tabular}

a. Predictors: (Constant), X3, X2, X1

b. Dependent Variable: Y

Sumber: Data diolah, 2017 (Lampiran 5)

Jumlah data (n) dalam penelitian ini adalah 36 dan jumlah variabel bebas (k) yang digunakan adalah 3, sehingga diketahui dL senilai 1,2953 dan dU senilai 1,6539. Berdasarkan hasil pengujian Durbin Watson pada Tabel 4.4 diketahui nilai sebesar 1,975 yang berada diantara nilai $\mathrm{dU}=1,6539$ sampai $4-\mathrm{dU}=2,3461$ atau $1,6539<1,975<2,3461$, sehingga dapat dikatakan data yang diteliti tidak terpengaruh gejala autokorelasi sehingga dapat dianalisis dalam persamaan regresi linier berganda.

Tujuan uji multikolinearitas adalah untuk menguji ada atau tidaknya korelasi antar variabel bebas dalam suatu model regresi. Kriteria model regresi yang tidak memiliki gejala multikolinearitas dapat diketahui melalui nilai tolerance $>0,1$ dan nilai VIF (Variance Inflation Factor) < 10. Uji multikolinearitas menunjukkan hasil yang dimuat dalam tabel 6 .

Tabel 6.

Hasil Uji Multikolinearitas

\begin{tabular}{llcc}
\hline & Model & \multicolumn{2}{c}{ Collinearity Statistics } \\
& & Tollerance & VIF \\
\hline 1 & (Constant) & 0,609 & \\
& Durasi & 0,624 & 1,642 \\
& Konveksitas & 0,944 & 1,603 \\
& Inflasi & & 1,509 \\
\hline
\end{tabular}

Sumber: Data diolah, 2017 (Lampiran 6) 
Ni Putu Rika Puspa Astari, Pengaruh Durasi, Konveksitas dan...

Tabel 6 menunjukkan bahwa nilai tolerance untuk variabel durasi, konveksitas dan inflasi adalah 0,609; 0,624 dan 0,944 dimana nilai tersebut lebih besar dibanding 0,1. Nilai VIF dari variabel durasi, konveksitas dan inflasi masingmasing sebesar 1,642; 1,603 dan 1,509 dimana nilai tersebut lebih kecil dari 10, maka dapat ditarik simpulan yaitu penelitian ini memiliki persamaan regresi yang bebas dari gejala multikolinearitas.

Uji heteroskedastisitas memiliki tujuan untuk mengungkap suatu model regresi memiliki ketidaksamaan varian residual suatu pengamatan yang lain atau tidak (Ghozali, 2013:139). Data regresi dikatakan bebas gejala heteroskedastisitas jika besaran signifikansi setiap variabel bernilai lebih dari 0,05. Uji heteroskedastisita memperoleh hasil yang dimuat pada tabel 7 berikut ini.

Tabel 7.

Hasil Uji Heteroskedastisitas

\begin{tabular}{llcc}
\hline \multicolumn{1}{c}{ Model } & t & \multicolumn{2}{c}{ Sig. } \\
\hline 1 (Constant) & 6,950 & .000 \\
Durasi & .693 & .494 \\
Konveksitas & .780 & .442 \\
Inflasi & .491 & .627 \\
\hline
\end{tabular}

Sumber: Data diolah, 2017 (Lampiran 7)

Tabel 7 memperlihatkan nilai signifikansi untuk variabel durasi, konveksitas dan inflasi yakni sebesar 0,494; 0,442 dan 0,627. Nilai itu secara keseluruhan lebih besar dibanding taraf signifikansi yang telah ditentukan yakni sebesar 0,05, maka dapat disimpulkan antara variabel bebas terhadap absolute residual tidak memiliki pengaruh satu sama lainnya. Hal itu mempertegas pernyataan terkait data regresi yang tidak mengandung gejala heteroskedastisitas. 
Uji regresi menggambarkan arah dan besarnya pengaruh variabel durasi, konveksitas dan inflasi terhadap harga obligasi korporasi di BEI periode 20142016. SPSS 21.0 for windows dimanfaatkan untuk melakukan analisis regresi linier berganda. Tabel 8 akan menjabarkan hasil analisis regresi berganda.

Tabel 8.

Hasil Analisis Regresi Linier Berganda

\begin{tabular}{|c|c|c|c|c|c|}
\hline \multirow[t]{2}{*}{ Model } & \multicolumn{2}{|c|}{$\begin{array}{l}\text { Unstadardize } \\
\text { Coefficient }\end{array}$} & \multirow{2}{*}{$\begin{array}{c}\text { Standardized } \\
\text { Coefficient } \\
\text { Beta }\end{array}$} & \multirow[t]{2}{*}{$\mathbf{t}$} & \multirow[t]{2}{*}{ Sig. } \\
\hline & B & $\begin{array}{l}\text { Std. } \\
\text { Error }\end{array}$ & & & \\
\hline 1 (Constant) & $-1,329$ & 0,646 & & $-.2,057$ & 0.048 \\
\hline Durasi & 1,102 & 0,385 & 0,558 & 2,867 & 0,007 \\
\hline Konveksitas & $-0,013$ & 0,011 & $-0,226$ & $-1,172$ & 0,250 \\
\hline Inflasi & 0,104 & 0,115 & 0,141 & 0,903 & 0,373 \\
\hline R Square & & & & & 0,260 \\
\hline Adjusted R Square & & & & & 0,191 \\
\hline F Statistik & & & & & 3,755 \\
\hline Signifikansi & & & & & 0,02 \\
\hline
\end{tabular}

Sumber: Data diolah, 2017 (Lampiran 3)

Persamaan regresi linier berganda sesuai dengan tabel 8 adalah sebagai berikut:

$$
Y=-1,329+1,102 X_{1}+-0,013 X_{2}+0,104 X_{3}+e
$$

Keterangan:

$$
\begin{array}{ll}
\mathrm{Y} & =\text { Harga Obligasi } \\
\mathrm{X}_{1} & =\text { Durasi } \\
\mathrm{X}_{2} & =\text { Konveksitas } \\
\mathrm{X}_{3} & =\text { Inflasi } \\
\mathrm{e} & =\text { error }
\end{array}
$$


Ni Putu Rika Puspa Astari, Pengaruh Durasi, Konveksitas dan...

Persamaan 7 mengungkapkan arah hubungan setiap variabel bebas dengan variabel terikatnya. Nilai $\alpha=-1,329$ berarti apabila nilai variabel durasi $\left(\mathrm{X}_{1}\right)$, konveksitas $\left(\mathrm{X}_{2}\right)$, dan inflasi $\left(\mathrm{X}_{4}\right)$ bernilai nol, nilai dari harga obligasi (Y) akan menunjukkan penurunan senilai $1,329 \%$. Nilai $\beta_{1}=1,102$ berarti setiap penambahan durasi $\left(\mathrm{X}_{1}\right)$ senilai 1 tahun yang diasumsikan dengan konstannya variabel bebas lain menyebabkan harga obligasi (Y) menunjukkan penambahan nilai sebesar $1,102 \%$. Nilai $\beta_{2}=-0,013$ berarti setiap peningkatan konveksitas $\left(\mathrm{X}_{2}\right)$ sebesar 1 tahun dengan asumsi variabel bebas lainnya konstan menyebabkan harga obligasi (Y) mengalami penurunan sebesar 0,013\%. Nilai $\beta_{3}=0,104$ berarti setiap penambahan inflasi $\left(\mathrm{X}_{3}\right)$ sebesar $1 \%$ yang diasumsikan dengan konstannya variabel bebas lain menyebabkan harga obligasi (Y) menerima penambahan nilai sebesar $0,104 \%$.

Uji koefisien determinasi yang dimuat dalam tabel 4.2 menggambarkan bahwa nilai Adjusted $R$ Square terkait data yang diteliti adalah sebesar 0,191 yang berarti hanya 19,1\% variasi dari variabel bebas (durasi, konveksitas dan inflasi) yang mampu menjelaskan variasi variabel terikat (harga obligasi), sementara sisanya yaitu $80,9 \%$ mampu direpresentasikan variabel bebas lain namun belum dimasukkan dalam analisis.

Hasil uji hipotesis untuk pengaruh variabel durasi terhadap harga obligasi dinyatakan dengan nilai $t_{\text {hitung }}=2,867>t_{\text {tabel }}=1,69389$ dan nilai signikansi 0,007 $<\alpha=0,05$ yang artinya variabel durasi memperlihatkan pengaruh positif signifikan terhadap harga obligasi korporasi di BEI periode 2014-2016. Hal ini berarti semakin lama durasi suatu obligasi, maka semakin tinggi pula risiko suatu obligasi 
mengalami perubahan harga pasar akibat adanya fluktuasi suku bunga. Pernyataan tersebut sesuai dengan teori yang mengungkapkan besar kecilnya durasi akan mempengaruhi volatilitas harga obligasinya (Manurung, 2006:40).

Tandelilin (2010:283) menyatakan bahwa durasi mampu menganalisis nilai sensitivitas harga obligasi terhadap pergerakan tingkat bunga secara lebih akurat karena durasi sudah memadukan antara kupon dan maturitas obligasi. Hanafi (2012:139) juga mengungkapkan bahwa semakin tinggi durasi, maka semakin tinggi pula volatilitas harga pasar sebuah obligasi, dengan kata lain bahwa semakin meningkat durasi menyebabkan semakin meningkat pula risiko perubahan tingkat bunga yang harus diantisipasi oleh penerbit maupun pemilik obligasi.

Hasil analisis memperkuat penelitian yang sebelumnya dilakukan oleh Sarkar (1999) yang mengungkapkan variabel durasi berpengaruh terhadap harga obligasi. Fruhwirth (2002) berpendapat durasi berpengaruh positif dan signifikan terhadap harga obligasi. Alouj (2002) dan Gajek et al. (2003) mengungkapkan pendapatnya yakni durasi mempunyai pengaruh positif pada harga obligasi. Shirvani dan Wilbratte (2005) juga memiliki pendapat durasi berpengaruh positif dan signifikan terhadap harga obligasi. Kusuma dan Asrori (2005) juga menyatakan bahwa durasi berpengaruh positif terhadap harga obligasi, dimana obligasi yang memiliki durasi lebih lama akan berhadapan dengan risiko yang semakin tinggi terkait fluktuasi suku bunga.

Chou et al. (2008) menyatakan bahwa durasi berpengaruh positif terhadap harga obligasi. Hahn dan Lange (2008) juga berpendapat yakni durasi menunjukkan pengaruh positif pada harga obligasi, dimana kupon dan perubahan yield dapat 
Ni Putu Rika Puspa Astari, Pengaruh Durasi, Konveksitas dan...

menjelaskan konsep finansial dari penggunaan durasi untuk memprediksi besar kecilnya sensitivitas harga obligasi akan fluktuasi suku bunga. Terakhir, Hyman et al. (2015) juga memiliki pendapat dimana durasi memiliki pengaruh positif terhadap harga obligasi.

Hasil uji hipotesis untuk pengaruh konveksitas terhadap harga obligasi dinyatakan dengan nilai $t_{\text {hitung }}=-1,172<t_{\text {tabel }}=1,69389$ dan nilai signikansi 0,250 $>\alpha=0,05$ yang artinya konveksitas menunjukkan pengaruh yang negatif dan tidak signifikan pada harga obligasi korporasi di BEI selama 2014-2016. Hal itu berarti semakin besar nilai konveksitas suatu obligasi, maka semakin kecil sensitivitas harga obligasi terhadap perubahan yield. Pernyataan yang diungkap pada penelitian ini sejalan dengan penelitian sebelumnya yang dilakukan oleh Kusuma dan Asrori (2005) yang mengungkapkan konveksitas memiliki pengaruh negatif dan tidak signifikan pada harga obligasi.

Terdapat beberapa alasan yang mengakibatkan hasilyang didapat tidak sesuai dengan hipotesis awal. Pertama, obligasi berjangka waktu singkat dengan kupon besar menjadi kurang konveks karena saat ditampilkan dalam bentuk kurva, tampilan kurva dari obligasi tersebut mendekati garis lurus (Kusuma dan Asrori, 2005). Pernyataan yang diungkapkan Kusuma dan Asrori (2005) sejalan dengan data yang dijadikan dasar analisis pada penelitian ini, dimana sampel obligasi yang dipilih termasuk dalam kriteria obligasi tersebut.

Kedua, kuantitas transaksi obligasi di Indonesia kurang lancar (likuid) yakni perubahan harga obligasi tidak terjadi secara rutin, dimana fluktuasi harga obligasi hanya terjadi apabila ada transaksi obligasi, serta fluktuasi tingkat bunga tak 
semuanya diikuti oleh fluktuasi harga sebuah obligasi di Indonesia. Ketiga, tidak semua data penelitian menyajikan fakta yang sejalan dengan hipotesis yang diajukan karena jika mengacu pada data, nilai konveksitas obligasi yang besar tidak selalu diikuti oleh perubahan harga obligasi yang besar pula (Kusuma dan Asrori, 2005).

Hasil uji hipotesis untuk pengaruh inflasi terhadap harga obligasi dinyatakan dengan nilai $t_{\text {hitung }}=0,903<\mathrm{t}_{\text {tabel }}=1,69389$ dan nilai signikansi $0,373>\alpha=0,05$ yang artinya inflasi menunjukkan pengaruh positif dan tidak signifikan pada harga obligasi korporasi di BEI selama tahun 2014-2016. Hal tersebut berarti semakin tinggi persentase inflasi, maka perubahan harga obligasi mengalami peningkatan. Nanga (2005:237) menyatakan bahwa tingkat harga yang dipengaruhi oleh inflasi adalah tingkat harga untuk komoditi atau barang secara umum. Pernyataan tersebut dapat berarti bahwa inflasi kurang mempengaruhi harga obligasi dikarenakan obligasi bukan merupakan salah satu komoditas yang bersifat umum.

Pernyataan yang berbanding terbalik dengan hipotesis ini sejalan dengan Widajati (2009) yang memiliki pendapat yakni meskipun inflasi memperlihatkan kecenderungan untuk naik, pemerintah tetap mengupayakan stabilitas ekonomi khususnya bagi pelaku pasar, sehingga tidak terdapat alasan fundamental yang memaksa pasar untuk menampilkan situasi pasar yang negatif. Azizah dan Hidajat (2016) ikut berpendapat yakni inflasi menunjukkan pengaruh positif dan tidak signifikan pada harga obligasi, dikarenakan besaran inflasi yang tergolong rendah yaitu kurang dari 10\% sehingga tidak mempengaruhi keputusan investor untuk membeli atau menjual obligasi. 
Ni Putu Rika Puspa Astari, Pengaruh Durasi, Konveksitas dan...

Pernyataan dari Azizah dan Hidajat (2016) sejalan dengan data rata-rata inflasi dalam penelitian ini yakni 6,42\% pada tahun 2014, 6,38\% pada tahun 2015 dan 3,53\% pada tahun 2016. Besaran inflasi tersebut masing-masing memiliki nilai kurang dari 10\%. Azizah dan Hidajat (2016) mengemukakan pendapat yakni sebaiknya memilih obligasi dengan jangka waktu lebih dari 5 tahun agar pengaruh variabel inflasi lebih representatif.

\section{IMPLIKASI HASIL PENELITIAN}

Berdasarkan hasil penelitian ini, hanya variabel durasi yang memiliki implikasi terhadap investor. Durasi mampu dijadikan acuan oleh investor guna mengukur volatilitas harga sebuah obligasi. Investor akan memilih obligasi dengan jangka waktu yang pendek, memiliki kupon besar dan mampu memberikan yield yang besar. Obligasi dengan karakteristik tersebut memiliki durasi yang pendek, sehingga harga obligasi korporasi yang dipilih memiliki sensitivitas rendah terhadap perubahan suku bunga.

\section{SIMPULAN DAN SARAN}

Berdasarkan hasil analisis dan pembahasan penelitian, maka simpulan dalam penelitian ini adalah durasi memperlihatkan pengaruh yang positif signifikan pada harga obligasi korporasi di BEI selama periode 2014-2016. Hal ini berarti semakin besar nilai durasi, maka semakin besar pula sensitivitas harga obligasi terhadap perubahan tingkat bunga. Konveksitas memperlihatkan pengaruh negatif dan tidak signifikan terhadap harga obligasi korporasi di BEI periode 2014-2016. Hal ini dikarenakan jangka waktu dari sampel obligasi pada penelitian ini cukup pendek, transaksi perdagangan obligasi di Indonesia kurang likuid dan ketidaksesuaian 
antara kondisi sebaran data dengan hipotesis penelitian. Inflasi menunjukkan pengaruh positif dan tidak signifikan pada harga obligasi korporasi di BEI periode 2014-2016. Hal ini disebabkan oleh inflasi di Indonesia pada tahun pengamatan memiliki nilai kurang dari $10 \%$ atau tergolong rendah, sehingga kurang berpengaruh terhadap harga obligasi.

Berdasarkan simpulan penelitian maka dapat disarankan beberapa hal diantaranya peneliti selanjutnya sebaiknya memilih obligasi korporasi dengan kode yang berbeda dan memiliki jangka waktu yang lebih panjang agar pengaruh variabel bebasnya lebih terlihat serta menambah variabel penelitian sehingga mampu memberikan gambaran lebih jelas terkait harga obligasi. Investor dapat menggunakan durasi sebagai salah satu cara untuk mengukur sensitivitas harga obligasi terhadap perubahan suku bunga di Indonesia. Terbukti bahwa durasi memberikan pengaruh positif signifikan pada harga sebuah obligasi korporasi di Indonesia. Perusahaan sebaiknya lebih cermat mengamati dinamika dan spekulasi perkembangan ekonomi sebelum menerbitkan obligasi. Perusahaan diharapkan mampu menjaga kualitas manajemennya untuk meningkatkan kepercayaan investor dalam berinvestasi khususnya melalui obligasi korporasi.

\section{REFERENSI}

Alouj, Hosein A, Nahid M Nia dan Seyed M S Amiri. 2012. Interest Rate Risk of Zero-coupon Bond Prices on Bombay Stock Exchange (BSE) - Empirical Test of the Duration, Modified Duration, Convexity and Immunization Risk. Australian Journal of Basic and Applied Sciences, 6, pp: 166-179.

Azizah, F, dan Imam H. 2016. Pengaruh Inflasi, Interest Rate SBI, Jauh Tempo, dan Nilai Tukar terhadap Harga Obligasi. Jurnal Ilmu dan Riset Manajemen, 5(2), h: 1-15.

Bareksa. 2017. Daftar Obligasi. http://www.bareksa.com/id/bond/list (diakses pada tanggal 7 Juli 2017). 
Barr, David F. dan J Y. Campbell. 1997. Inflation, Real Interest Rate, and the Bond Market: A Study of UK Nominal and Index-linked Government Bond Prices. Journal of Monetary Economics, 39(3), pp: 361-383.

Brigham, E F., dan J F. Houston. 2011. Dasar-dasar Manajemen Keuangan. Edisi 10. Jakarta: Salemba Empat.

Cerovic, S, M Pevic, Stanislav C dan Nevena C. 2014. Duration and Convexity of Bonds. Singidunum Journal of Applied Science, 11(1), pp: 53-66.

Chou, Jian-Hshin, Hong-Fwu Yu dan Chien-Yun Chang. 2008. An Accurate Measure of Callable Bond Price Sensitivity to Interest Rates and Passage of Time. Journal of Statistics and Management Systems, 11 (3), pp: 517-543.

Fabozzi, J F. 2000. Manajemen Investasi. Buku Dua. Jakarta: Salemba Empat.

Fruhwirth, M. 2002. The Heath-Jarrow-Morton Duration and Convexity: A Generalized Approach. International Journal of Theoretical and Applied Finance, 6(7), pp: 1-34.

Gajek, L, Krzysztof O dan Hans J Zwiesler. 2005. A Primer on Duration, Convexity, and Immunization. Journal of Actuarial Practice, 12, pp: 59-82.

Ghozali, Imam. 2012. Analisis Multivariate Lanjutan dengan Program SPSS. Semarang: Universitas Diponogoro.

Hahn, Tewahn dan David Lange. 2008. Teaching Bond Valuation: A Differential Approach Demonstrating Duration and Convexity. Journal of Economic and Finance Education, 7(2), pp: 13-19.

Hamid, Abdul, Ahmad Rodoni, Titi Dewi W dan Edi Hidayat. 2006. Analisis Durasi dan Convexity untuk Mengukur Sensitivitas Harga Obligasi Korporasi terhadap Perubahan Tingkat Suku Bunga (Studi Empiris pada Obligasiobligasi di Indonesia). Jurnal Fakultas Ekonomi Universitas Islam Negeri Jakarta, 6(2), h: 117-142.

Hanafi. Mamduh M. 2012. Manajemen Risiko. Edisi Kedua. Yogyakarta: UPP STIM YKPN.

Hartono, J. 2016. Teori Portofolio dan Analisis Investasi. Edisi Kesepuluh. Yogyakarta: BPFE.

Hordahl, Peter dan Oreste Tristani. 2014. Inflation Risk Premia in the Euro Area and United States. International Journal of Central Banking, 10(3), pp: 1-47.

Hyman, J, Arik B Dor, Lev D, David H dan Zhe Xu. 2015. Coupon Effect on Corporate Bonds: Pricing, Empirical Duration and Spread Convexity. The Journal of Fixed Income Winter, 24 (3), pp: 52-63.

Indonesia Bond Pricing Agency. 2017. Perkembangan Investasi Obligasi Korporasi.

http://www.ibpa.co.id/BeritadanPeristiwa/ArsipBerita/tabid/126/EntryId/729 6/Sepanjang-2016-Penerbitan-Obligasi-dan-Sukuk-Capai-Rp90-53Triliun.aspx (diakses pada tanggal 7 Juli 2017). 
Kang, Johnny dan Caroline E. Pflueger. 2012. Inflation Risk in Corporate Bonds. Journal of Economic, pp: 1-38.

Kusuma, H dan Asrori. 2005. Pengaruh Durasi dan Konveksitas terhadap Sensitivitas Harga Obligasi. Jurnal Fakultas Ekonomi Universitas Islam Indonesia, 7(2), h: 35-52.

Lajili, Souad dan Yves Rakotrondatsimba. 2012. Enhancement of Bond DurationConvexity Approximation. International Journal of Economics and Finance, 4(3), pp: 115-125.

Lena, Jacky Kale dan Apriani Dorkas Rambu Atahau. 2003. Pengaruh Durasi Obligasi untuk Mengetahui Sensitivitas Harga Obligasi terhadap Perubahan Tingkat Suku Bunga di Indonesia. Jurnal Ekonomi dan Bisnis (Dian Ekonomi), 9(1), h: 1-14.

Manurung, A H. 2006. Dasar-dasar Investasi Obligasi. Jakarta: Gramedia.

Manurung, Adler H. dan Lutfi T. Rizky. 2009. Successful Financial Planner: A Complete Guide. Jakarta: Grasindo.

Maruddani, D Asih I dan A Hoyyi. 2017. Perbandingan Sensitivitas Harga Obligasi Berdasarkan Durasi Macaulay dan Durasi Eksponensial dengan Pengaruh Konveksitas. E-Jurnal Media Statistika, 10(1), h: 11-22.

Nanga, M. 2005. Makroekonomi Teori, Masalah dan Kebijakan. Jakarta: Rajawali Press.

Purba, A. 2016. Analisis Pengaruh Likuiditas Obligasi, Waktu Jatuh Tempo dan Kupon Obligasi terhadap Harga Obligasi Korporasi di Bursa Efek Indonesia (BEI). Skripsi Fakultas Ekonomi dan Bisnis Universitas Lampung.

Putong, I. 2013. Pengantar Ekonomi Mikro dan Makro. Jakarta: Ghalia Indonesia.

Rose, A K. dan Mark M. Spiegel. 2015. Domestic Bond Markets and Inflation. Working Papers of Federal Reserve Bank of San Francisco, pp: 1-38.

Sari, Purnama dan K Sudjarni. 2016. Pengaruh Likuiditas Obligasi, Waktu Jatuh Tempo dan Kupon Obligasi terhadap Perubahan Harga Obligasi Korporasi Berperingkat. E-Jurnal Manajemen Unud, 5(4), h: 2283-2310.

Sarkar, S. 1999. Duration and Convexity of Zero-Coupun Convertible Bond. Journal of Economics and Business, 51, pp: 175-192.

Shirvani, Hassan dan Barry Wilbratte. 2005. Duration and Bond Prices Volatility: Some Further Results. Journal of Economic and Business Education, 4(1), pp: 1-6.

Sugiyono. 2014. Metode Penelitian Bisnis. Bandung: Alfabeta

Sukanto, Eman dan Widaryanti. 2015. Pengaruh Rate Bunga Deposito, Nilai Tukar Rupiah dan Besaran Inflasi terhadap Harga Obligasi Pemerintah Republik Indonesia (Periode 2009-2013. Jurnal Dinamika Ekonomi dan Bisnis, 12(2), h: 132-149. 
Sulistiawati, R. M. 2014. Pengaruh Suku Bunga SBI, IHSG dan Inflasi terhadap Obligasi Pemerintah di Indonesia. Skripsi Fakultas Ekonomi Universitas Airlangga.

Sunariyah, A. 2011. Pengantar Pengetahuan Pasar Modal. Edisi Keenam. Yogyakarta: BPFE.

Sunaryo, T. 2007. Manajemen Risiko Finansial. Jakarta: Salemba Empat.

Sotos, Francisco E. 2004. Duration and Convexity in Spanish Corporate Bonds. International Advances in Economic Research, 10 (4), pp: 273-277.

Tandelilin, E. 2010. Portofolio dan Investasi. Edisi pertama. Yogyakarta: Kanisius.

Utama, Suyana. 2016. Buku Ajar Aplikasi Analisis Kuantitatif untuk Ekonomi dan Bisnis. Edisi Kesepuluh. Denpasar: Sastra Utama.

Wahyuningsih, S. 2003. Analisis Faktor-faktor yang Mempengaruhi Harga Obligasi Syariah yang Terdaftar di Bursa Efek Indonesia. Skripsi Fakultas Syariah dan Hukum Universitas Islam Negeri Sunan Kalijaga.

Wiagustini, Ni Luh Putu. 2014. Manajemen Keuangan. Denpasar: Udayana University Press.

Widajati, A. 2009. Inflasi dan Tingkat Bunga terhadap Harga Obligasi Negara Ritel yang Diterbitkan Pemerintah. Jurnal Keuangan dan Perbankan, 13(1), h: 97105.

Widoatmodjo, S. 2008. Cara Sehat Investasi di Pasar Modal. Edisi Revisi. Jakarta: PT. Elex Media Komputindo. 